УДК 631.52:635.25:631.521:001.4:631.559

(C) 2012

Борисенко Л. Д., Катаєва Т. Є., кандидати сільськогосподарських наук

Донецька дослідна станція Інституту овочівництва і баштанництва НААНУ

\title{
ПЕРСПЕКТИВИ АДАПТИВНОЇ СЕЛЕКЦІЇ РАННЬОСТИГЛИХ СОРТІВ ЦИБУЛІ РІПЧАСТОЇ
}

\section{Рецензент - кандидат економічних наук Г. В. Сергєєв}

Наведено результати багаторічного вивчення колекиійного матеріалу ичибулі ріпчастої в двох географічних пунктах. У результаті проведення екологічного випробування підібрано перспективні ранньостиглі лінії ичибулі ріпчастої за коротким (до 100 діб) періодом вететаиії, а також високопродуктивні зразки, лежкі й стійкі до біотичних $i$ абіотичних чинників. Доведено ефективність доборів морфологічних ознак, за якими слід проводити прискорений добір на продуктивність. Для подальшої роботи відібрано рослини з джерел, які мали найбільший адаптивний потенціал із комплексом господарськи иінних ознак.

Ключові слова: селекція, ичибул ріпчаста, сорт, випробування, врожайність

Постановка проблеми. Більшість сучасних сортів і гетерозисних гібридів $\mathrm{F}_{1}$ цибулі ріпчастої, що пропонуються селекційними установами, мають високий рівень потенційної врожайності. Реалізація іiі залежить від багатьох факторів і часто досить не співпадає з отриманою у виробництві. Одним із найбільш важливих неконтрольованих факторів, який впливає на формування врожаю, є екологічний. Високий рівень адаптивності до екологічних умов забезпечує стабільність реалізації потенційних можливостей генотипу, будучи необхідною умовою їх конкурентоздатності. Для цілеспрямованої роботи зі створення високоадаптованих сортів i гібридів $F_{1}$ необхідні знання характеру взаємозв'язку селекційних ознак із їх стабільністю за роками. Тому особливості клімату кожної зони обумовлюють проведення адаптивної селекції та створення нових сортів цибулі ріпчастої [3].

Аналіз основних досліджень і публікацій, у яких започатковано розв'язання проблеми. Літературні дані свідчать, що 3 підвищенням урожайності сортів знижуються їх адаптивні можливості. Інші дані вказують на відсутність такої залежності, тому питання залишається власне відкритим. Відомо, що цибуля ріпчаста має вузьку географічну локалізацію, в силу своєї фотоперіодичної реакції. Зазвичай для кожної зони вирощування потрібен набір сортів, адаптованих до місцевих умов. Регіони також можуть характеризуватися різними грунтово-кліматичними умовами. Одним з основних факторів, лімітуючих урожайність цибулі ріпчастої, $є$ дефіцит зволоження. Аналіз кліматичних даних показав, що в лісостеповій зоні України можуть вирощуватися сорти різних груп стиглості, тоді як у степовій доцільні ранньостиглі.

Мета і завдання досліджень. Метою дослідної роботи було вивчення явища скоростиглості, як комплексу фізіологічних процесів і морфоанатомічних особливостей та їх успадкування у процесі створення ранньостиглих сортів із стабільним проявом ознаки залежно від зони вирощування.

Матеріали і методи досліджень. Науководослідну роботу зі створення цибулі ріпчастої проводили у творчій співпраці з лабораторією селекції дворічних рослин ІОБ НААН за повною схемою селекційного процесу методом синтетичної селекції з залученням до покрокової статевої гібридизації екологічно віддалених зразків, а також гібридів власної селекції. Крім того вели прямий індивідуальний та родинний добір ранньостиглих і посухостійких генотипів відповідно до «Сучасних методів селекції овочевих і баштанних культур», «Методики проведення експертизи сортів на відмінність, однорідність та стабільність (ВОС)» $\mathrm{i}$ «Методичних рекомендацій 3 селекції...» $[1,4$, 6]. Дослідження супроводжувалися фенологічними спостереженнями за ростом і розвитком рослин, їх описом та біометрією. Стійкість проти хвороб визначали на природному інфекційному фоні. Випробування нових ліній проводили за методикою Державного сортовипробування [5], математичний обробіток даних врожаю - методом дисперсійного аналізу [2]. За роки досліджень погодні умови відрізнялися, що допомогло зробити добори на адаптивність, а своєчасно проведені агротехнічні прийоми також сприяли селекційному процесу.

Об'єктом досліджень був власний вихідний матеріал, лінії місцевої селекції, а також сортозразки лабораторії селекції дворічних рослин 
ІОБ НААН і світової колекції ВІР.

Сівбу проводили вручну в першій декаді квітня. Схема посіву у дослідах стрічкова $-0,7$ м. Площа ділянок $-3,5-10 \mathrm{~m}^{2}$. Технологія вирощування рослин - загальноприйнята для степової та лісостепової зон України.

Результати досліджень. Для виконання наукової програми селекційні лінії оцінювалися в різних за віком розсадниках. Окрім власних до- сліджень вони були направлені на зональне вивчення до Інституту овочівництва і баштанництва НААН. Розсадники закладено для визначення господарськи цінних ознак вихідного матеріалу залежно від зони вирощування (Степ і Лісостеп).

У степовій зоні України вивчали 10 місцевих ліній у порівнянні з ранньостиглими стандартами. В результаті досліджень відмічено 7 найбільш цінних для селекції (табл. 1).

\section{1. Результати оцінки зразків цибулі ріпчастої в зоні стеny, 2011 р.}

\begin{tabular}{|c|c|c|c|c|c|c|c|c|}
\hline \multirow{3}{*}{ Назва зразка } & \multicolumn{6}{|c|}{ Урожайність } & \multirow{3}{*}{$\begin{array}{l}\text { Маса ци- } \\
\text { булини, г }\end{array}$} & \multirow{3}{*}{$\begin{array}{c}\text { Вегетацій- } \\
\text { ний період, } \\
\text { діб }\end{array}$} \\
\hline & \multicolumn{3}{|c|}{ загальна } & \multicolumn{3}{|c|}{ товарна } & & \\
\hline & т/га & $\%$ до $\mathrm{st}_{1}$ & $\%$ до $\mathrm{st}_{2}$ & $\mathrm{~T} / \mathrm{\Gamma a}$ & $\%$ до $\mathrm{st}_{1}$ & $\%{\text { до } \mathrm{st}_{2}}$ & & \\
\hline $365(213214245 / 2)$ & 37,0 & 117 & 116 & 36,3 & 118 & 117 & 88 & 91 \\
\hline $365(213214245)$ & 36,4 & 115 & 114 & 35,7 & 116 & 115 & 86 & 90 \\
\hline $368(801)$ & 38,0 & 120 & 119 & 36,9 & 120 & 119 & 93 & 89 \\
\hline $372(13887216)$ & 39,6 & 125 & 124 & 38,6 & 125 & 124 & 91 & 101 \\
\hline 376 (13037194) & 35,2 & 111 & 110 & 34,2 & 111 & 110 & 87 & 89 \\
\hline 245 (130871941304) & 38,2 & 121 & 119 & 37,1 & 121 & 119 & 90 & 90 \\
\hline 443 (13059577) & 40,7 & 129 & 127 & 39,9 & 130 & 128 & 96 & 103 \\
\hline Рубін $\left(\mathrm{st}_{1}\right)$ & 31,6 & 100 & 99 & 30,7 & 100 & 99 & 72 & 87 \\
\hline Славний $\left(\mathrm{st}_{2}\right)$ & 32,0 & 101 & 100 & 31,1 & 101 & 100 & 79 & 88 \\
\hline $\mathrm{HIP}_{05}$ & 1,1 & & & 1,0 & & & & \\
\hline
\end{tabular}

2. Результати оцінки зразків цибулі ріпчастої в зоні лісостепу, 2011 р.

\begin{tabular}{|c|c|c|c|c|c|c|}
\hline \multirow{3}{*}{ Назва зразка } & \multicolumn{4}{|c|}{ Урожайність } & \multirow{3}{*}{$\begin{array}{l}\text { Маса ци- } \\
\text { булини, г }\end{array}$} & \multirow{3}{*}{$\begin{array}{c}\text { Вегетацій- } \\
\text { ний період, } \\
\text { діб }\end{array}$} \\
\hline & \multicolumn{2}{|c|}{ загальна } & \multicolumn{2}{|c|}{ товарна } & & \\
\hline & т/га & $\%$ до $\mathrm{st}_{3}$ & т/га & $\%$ до $\mathrm{st}_{3}$ & & \\
\hline $370(213214245 / 2)$ & 56,8 & 148 & 44,9 & 200 & 71 & 82 \\
\hline $368(801)$ & 35,3 & 92 & 21,5 & 96 & 42 & 92 \\
\hline $365(213214245)$ & 28,4 & 74 & 14,7 & 66 & 38 & 93 \\
\hline 444 (13037194) & 38,8 & 101 & 32,4 & 145 & 60 & 94 \\
\hline $446(13037194)$ & 38,9 & 101 & 27,0 & 121 & 51 & 102 \\
\hline $366(13087216)$ & 31,1 & 81 & 25,2 & 113 & 54 & 94 \\
\hline 443 (13059577) & 33,8 & 88 & 28,8 & 129 & 59 & 94 \\
\hline $245(130871941304)$ & 20,7 & 54 & 15,7 & 71 & 53 & 94 \\
\hline Ткаченівська st & 38,4 & 100 & 22,4 & 100 & 48 & 109 \\
\hline $\mathrm{HIP}_{05}$ & 2,7 & & 3,1 & & & \\
\hline
\end{tabular}

За загальним і товарним урожаєм цибулин виділилися зразки 368 (801), 245 (130871941304), 372 (13887216) та 443 (13059577). На рівні ранньостиглих стандартів за вегетаційним періодом відзначилися лінії 368 (801), 376 (13037194), 245 (130871941304) та $365(213214245 / 2)$. Всі зразки за лежкістю перевищували стандарти, а найбільша маса цибулини була у 443 (13059577), 368 (801), 372 (13887216) та 245 (130871941304). У розсаднику другого року життя рослин матеріал оцінювали на лежкість, ураженість хворобами зберігання, ранньостиглість (по цвітінню) та малозачатковість. Відмічено родини з високими міцними квітконосами, крупними суцвіттями та слабо сприйнятливі проти пероноспорозу. За комплексом корисно-цінних ознак виділено 4 лінії.

У Лісостепу України вивчали 10 ліній у порівнянні з продуктивним стандартом. У результаті досліджень виділено 8 кращих (табл. 2).

Загальна врожайність зразків коливалася від 20,7 т/га до 56,8 т/га. Стандарт перевищувала одна лінія $370 \quad(213214245 / 2), \quad$ дві - 444 (13037194) і 446 (13037194) були на рівні. За товарною врожайностю виділилася лінія 370 (213214245/2), яка на $200 \%$ перевищувала стандарт, а зразки 444 (13037194), 443 (13059577), 446 (13037194) та 366 (13087216) теж мали пере- 
вагу. За масою цибулини відмічено лінії 370 (213214245/2), 444 (13037194) i 443 (13059577). За вегетаційним періодом усі зразки, за винятком 446 (13037194), проявили себе як ранньостиглі, а найкоротший період був у 370 (213214245/2). За комплексом корисно цінних ознак виділено 3 лінії.

\section{БІБЛІОГРАФІЯ}

1. Горова Т. К., Борисенко Л. Д., Яровий Г. I. [mа ін.]. Селекція, технологічні прийоми та особливості насінництва багаторічних цибуль: методичні рекомендації. - Х., 2006. - 24 с.

2. Доспехов Б. А. Методика полевого опыта. - М. : Колос, $1973 .-366 \mathrm{c}$.

3. Жученко A. А. Адаптивная система селекции растений (экологические основы): В 2 т. - М. : Изд-во РУДН, 2001. - Т. 1. - 780 с.

4. Методика проведення експертизи сортів на відмітність, однорідність та стабільність (ВОС) //
Висновки. У результаті екологічного випробування в двох географічних пунктах виділено перспективні ранньостиглі лінії цибулі ріпчастої за коротким періодом вегетації, що мали найбільший адаптивний потенціал. Визначено їх господарськи цінні ознаки для майбутньої селекційної роботи.

Охорона прав на сорти рослин.- Ч. 2.- К., 2004. - C. 221-228.

5. Методика державного сортовипробування сільськогосподарських культур.- К., 2000.Вип. 1. - $100 \mathrm{c}$.

6. Чернишенко Т. В., Яковенко К. І., Біленька О. М., Дьоміна Н. Г. Сучасні методи селекції овочевих і баштанних культур: методичні рекомендації по селекції овочевих рослин родини цибулевих (Alliaceae) // За ред. Т. К. Горової, I. І. Яковенка. - Х. : ІОБ УААН, 2001. - 641 с. 